\title{
海猽頭蓋底骨膜下異物挿入例に 於けろ腦脊髓液壓所見
}

\author{
專修科生 吉 岡 彥 太郎
}

(京都帝國大學醫緮部耳鼻咽喉科敎室[圭任星野教授])

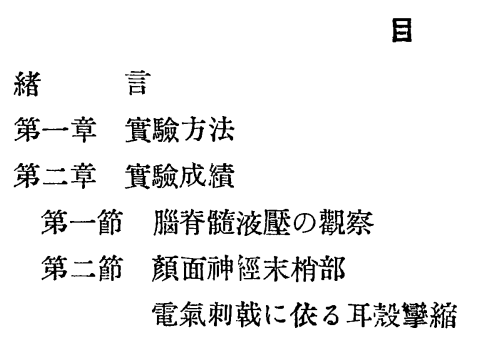

\section{緒言}

腦壓, 腦脊髓液壓變化が瞀䃼經柔統機 能に一定の影響を及すは巳に星を野敉室に 於て諸研究者 ${ }^{1223344}$ により實驗的に證明 せられをる所なり。

余は余の觀察せる海獏一側聽神轱幹壓 迫實驗例飞於ける術側耳款反射の減弱が 聽种經幹周圍飞充填せる異物の膨張に因

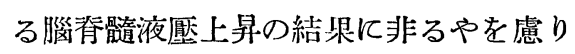
實驗例及對照實驗例に就き觀察したるに 兩者に於て腦疽䯣液壓に同㥞に一時的變 化を認むるる余の實驗例に於ける耳款反 射の變化は腦瓷䯣液涯變化乞直接因果關 係なをを確め得たり。

\section{第一章 實驗方法}

實驗動物 體重 450--600 gr 聖器器視器 に異常を認めざる健康海猈を撰ぶ.

腦脊髓液壓測定方法 星野呚室に於け
次

運動の觀察

第三節 音響性耳钥反射の觀察 第三章 總括前に考按 第四章 結 論 引用書目

る梶川の方法に據れり。供試海堔を星野 式固定器に腹位に縛着し其部を眼裂地平 面下約 $45^{\circ}$ 亿交叉せしめて固定し項部を 剃毛し後頭蓋骨及第一莖椎間に於て蠏蛛 膜下腔に穿刺針老刺入し流出する腦盗䯣 液を $0.96 \%$ 食監水を充せる硝子製目盛管 中に導き食監水柱の高さを测定す（單位 m.m.)

頭蓋底骨膜下異物充填方法 余等 ${ }^{5}$ の 慣行せる術式により左側錐體後面の骨膜 を剥離し聽神經顏面神經を通ずる骨孔の 周園を繞りて骨膜下にடラミナリヤ?系を 充塡す(第一群と略記す).

猶對㸃的に他の海獏の左側雓體後面骨 膜を剩離し聽种經孔と岩栐小葉筒の前下

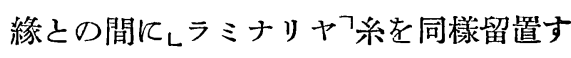
(第二群之略記す).

耳殻摹縮運動觀察方法 海晖の兩側對 
耳玟を夫々ーヶの書槓に連繫し電氣刺戟 及音響刺戟に依る耳款拿縮 運動により しミオグラフイオンフ上の煤煙紙表面に畫 く曲線により其反射時, 經過時間及振幅 高を測定す.

感傳電氣刺戟方法 白金製兩極 導子 (兩極間距離 $1.0 \mathrm{~mm}$ ) を對耳珠下方 $1.0 \mathrm{~cm}$ の皮膚面に貼用し兩橔をDu Bois Reymond 氏裝置の第二捲線包路に繫ぎ第一
抧線包路 (電源 $3.0 \mathrm{~V}$ ) 開放時感應電流によ り刺戟す。

畐響刺戟方法 一側耳正横方向 $10 . \mathrm{cm}$ の位置にェーデルマン氏改良ガルトン笛 $\left(\mathrm{a}^{5}\right)$ を定置し 20 m.m.Hg 涯の空氣により 吹鳴す.

非刺戟側耳は栓塞す.

\section{第二章 實 驗 成 績}

第一節 腦脊髓液壓の觀察

第一表 第 1 群に於げる腦脊艏液壓(m.m.0.96\%食臨水柱)

\begin{tabular}{|c|c|c|c|c|c|c|c|c|c|c|c|c|c|c|}
\hline \multirow{2}{*}{ 海 } & \multirow{2}{*}{ 猽 } & \multicolumn{4}{|c|}{ 健＼cjkstart常＼cjkstart時 } & \multicolumn{4}{|c|}{ 術 後 1 日 } & \multicolumn{2}{|c|}{ 術 後 3 日 } & \multicolumn{3}{|c|}{ 術 後 7 日 } \\
\hline & & 最 & 高 & 最 & 低 & 最 & 高 & 最 & 低 & 最 高 & 最 低 & 最 & 最 & 低 \\
\hline \multicolumn{2}{|c|}{ Nr. 752} & & 60 & & 57 & & 61 & & 59 & 130 & 124 & 78 & & 74 \\
\hline \multicolumn{2}{|c|}{ Nr. 753} & & 54 & & 50 & & 45 & & 42 & 108 & 105 & 57 & & 52 \\
\hline \multicolumn{2}{|c|}{ Nr. 754} & & 59 & & 56 & & 53 & & 50 & 100 & 97 & 55 & & 53 \\
\hline 平 & 均 & & 58 & & 54 & & 53 & & 50 & 113 & 109 & 6 & & 60 \\
\hline
\end{tabular}

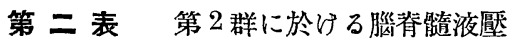

\begin{tabular}{|c|c|c|c|c|c|c|c|c|c|c|c|}
\hline \multirow{2}{*}{ 海 } & \multirow{2}{*}{ 猽 } & \multicolumn{2}{|c|}{ 健＼cjkstart常＼cjkstart時 } & \multicolumn{3}{|c|}{ 術 後 1 日 } & \multicolumn{2}{|c|}{ 術 後 3 日 } & \multicolumn{3}{|c|}{ 術 後 7 日 } \\
\hline & & 最 高 & 最 低 & 最 高 & 最 & 低 & 最 高 & 最 低 & 最 高 & & 低 \\
\hline \multicolumn{2}{|c|}{ Nr. 752} & 52 & 48 & 42 & & 36 & 102 & 98 & 50 & & 46 \\
\hline \multicolumn{2}{|c|}{ Nr. 763} & 52 & 48 & 48 & & 43 & 104 & 100 & 50 & & 46 \\
\hline \multicolumn{2}{|c|}{ Nr. 764} & 60 & 52 & 52 & & 47 & 113 & 108 & 60 & & 57 \\
\hline \multicolumn{2}{|c|}{ Nr. 765} & 65 & 60 & 53 & & 50 & 107 & 102 & 68 & & 62 \\
\hline 本 & 均 & 59 & 54 & 49 & & 46 & 107 & 102 & 57 & & 53 \\
\hline
\end{tabular}

第一群及第二群海獏に於ける術後の腦 脊髓液壓の變化は兩者共に術後 3 日に於 て立進す. 術後 7 日に到れば再び健常時 厴に接近す.

第二節 顏面神經末梢部電氣刺戟に 依る耳殻繁縮運動の觀察

第三表 第 1 群 R.A. $10 \mathrm{~cm}(3.0 \mathrm{~V})$ 開放時刺戟に依る耳款運動

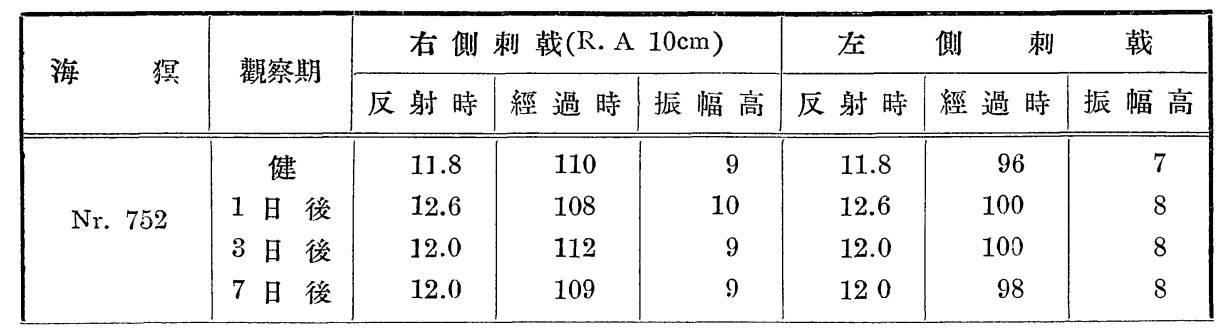




\begin{tabular}{|c|c|c|c|c|c|c|c|}
\hline Nr. 753 & \begin{tabular}{lll} 
& \multicolumn{2}{l}{ 健 } \\
1 & 日 後 \\
3 & 日 & 後 \\
7 & 日 & 後
\end{tabular} & $\begin{array}{l}12.8 \\
14.7 \\
13.0 \\
14.0\end{array}$ & $\begin{array}{l}137 \\
130 \\
130 \\
132\end{array}$ & $\begin{array}{l}12 \\
10 \\
10 \\
11\end{array}$ & $\begin{array}{l}12.8 \\
14.7 \\
13.0 \\
14.0\end{array}$ & $\begin{array}{l}129 \\
125 \\
120 \\
130\end{array}$ & $\begin{array}{r}10 \\
10 \\
9 \\
10\end{array}$ \\
\hline Nr. 754 & \begin{tabular}{lll} 
& \multicolumn{2}{l}{ 健 } \\
1 & 日 & 後 \\
3 & 日 & 後 \\
7 & 日 & 後
\end{tabular} & $\begin{array}{l}13.1 \\
15.0 \\
13.5 \\
13.0\end{array}$ & $\begin{array}{l}123 \\
120 \\
124 \\
120\end{array}$ & $\begin{array}{l}13 \\
12 \\
13 \\
12\end{array}$ & $\begin{array}{l}13.1 \\
15.0 \\
13.5 \\
13.0\end{array}$ & $\begin{array}{r}100 \\
98 \\
102 \\
100\end{array}$ & $\begin{array}{l}7 \\
8 \\
8 \\
8\end{array}$ \\
\hline 均 & \begin{tabular}{lll} 
& \multicolumn{2}{l}{ 健 } \\
1 & 日 & 後 \\
3 & 日 & 後 \\
7 & 日 & 後
\end{tabular} & $\begin{array}{l}12.6 \\
14.1 \\
12.8 \\
13.0\end{array}$ & $\begin{array}{l}123 \\
119 \\
122 \\
120\end{array}$ & $\begin{array}{l}11 \\
11 \\
11 \\
11\end{array}$ & $\begin{array}{l}12.6 \\
14.1 \\
12.8 \\
130\end{array}$ & $\begin{array}{l}108 \\
108 \\
107 \\
109\end{array}$ & $\begin{array}{l}8 \\
9 \\
8 \\
9\end{array}$ \\
\hline
\end{tabular}

（反射時，經過時單位 $\frac{1}{1000}$ 秒振幅高單位 $\mathrm{m} . \mathrm{m}$ 以下同じ）

第四 表 第 2 群海猽に於げる耳殻等縮運動

\begin{tabular}{|c|c|c|c|c|c|c|c|c|}
\hline \multirow{2}{*}{ 海 } & \multirow{2}{*}{ 猽 } & \multirow{2}{*}{ 觀察期 } & \multicolumn{3}{|c|}{ 右側刺戟(R.A $10 \mathrm{~cm}$ ) } & 左 & 側 & \\
\hline & & & 反 射 時 & 經過 時 & 振 幅高 & 反射 時 & 經 過 時 & 振 幅 高 \\
\hline \multirow{4}{*}{ Nr. } & \multirow{4}{*}{762} & 倠 & 12.5 & 128 & 12 & 12.5 & 125 & 10 \\
\hline & & 1 日 後 & 13.2 & 126 & 11 & 13.2 & 126 & 10 \\
\hline & & 3 日 後 & 13.8 & 128 & 9 & 13.8 & 128 & 11 \\
\hline & & 7 日 後 & 12.2 & 130 & 13 & 12.2 & 136 & 12 \\
\hline \multirow{4}{*}{ Nr. } & \multirow{4}{*}{763} & 健 & 13.9 & 136 & 10 & 13.9 & 133 & 13 \\
\hline & & 1 日 娞 & 13.6 & 136 & 10 & 13.6 & 138 & 13 \\
\hline & & 3 日 後 & 13.2 & 132 & 11 & 13.2 & 145 & 14 \\
\hline & & 7 日 後 & 13.8 & 140 & 13 & 13.8 & 138 & 15 \\
\hline \multirow{4}{*}{ Nr. } & \multirow{4}{*}{764} & 健 & 12.8 & 142 & 19 & 12.8 & 133 & 15 \\
\hline & & 1 日 後 & 12.7 & 150 & 20 & 12.7 & 130 & 14 \\
\hline & & 3 日 後 & 12.2 & 140 & 19 & 12.2 & 124 & 13 \\
\hline & & 7 日 後 & 12.6 & 134 & 18 & 12.6 & 124 & 14 \\
\hline \multirow{4}{*}{$\mathrm{Nr}$. } & \multirow{4}{*}{765} & 健 & 11.8 & 106 & 9 & 11.8 & 108 & 10 \\
\hline & & 1 日 後 & 12.0 & 107 & 9 & 12.0 & 110 & 10 \\
\hline & & 3 日 後 & 13.2 & 110 & 7 & 13.2 & 108 & 9 \\
\hline & & 7 日 後 & 11.3 & 98 & 8 & 11.3 & 114 & 11 \\
\hline \multirow{4}{*}{ 平 } & \multirow{4}{*}{ 均 } & 健 & 12.8 & 128 & 13 & 12.8 & 125 & 12 \\
\hline & & 1 日 後 & 12.9 & 130 & 13 & 12.9 & 126 & 12 \\
\hline & & 3 日 後 & 13.1 & 128 & 12 & 13.1 & 126 & 12 \\
\hline & & 7 日 後 & 12.5 & 126 & 13 & 12.5 & 128 & 13 \\
\hline
\end{tabular}


第一群及第二群海堔の術側及非術側顔間を通じて著變なし。

面神經未妳部電氣刺戟による耳款摹縮運

第三節 音響性耳殼反射の觀察

動の反射時經過時間，振幅高は全觀察期

第五表 第 1 群に於ける音響性 $\left(\mathrm{a}^{5}\right)$ 耳殻反射

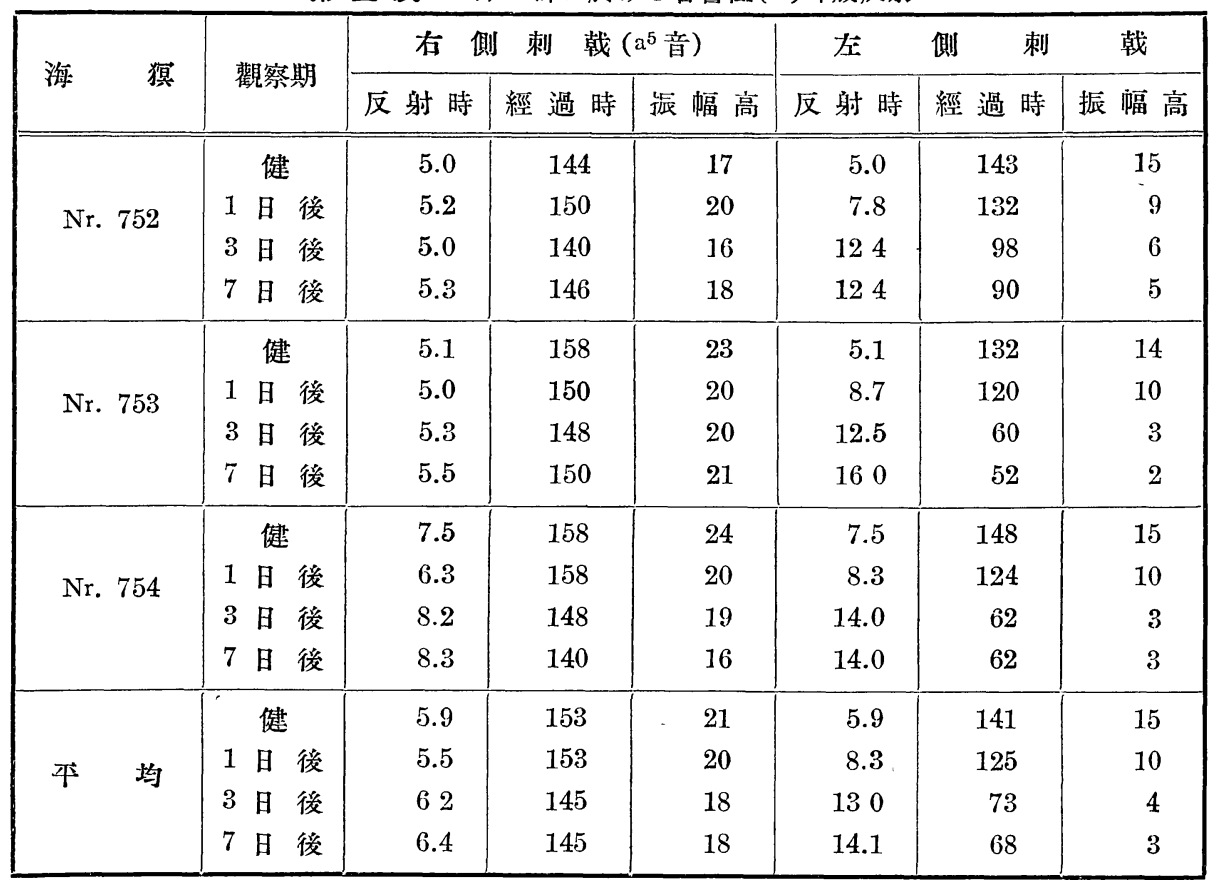

第六表 第2 群に於けろ音響性耳殼反射

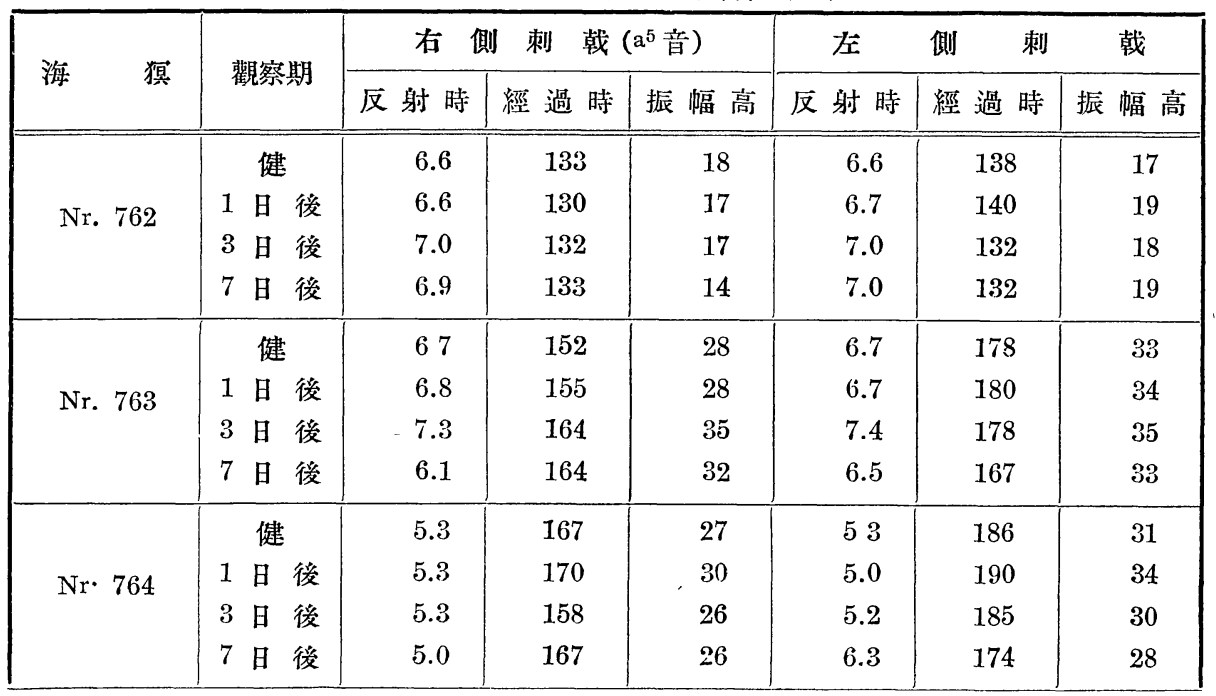




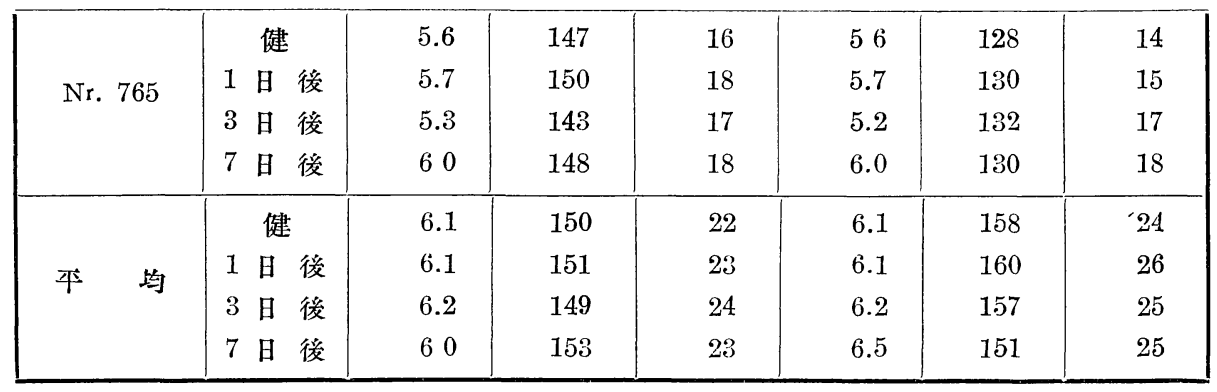

第一群海猽の術側音響性耳没反射は術 後時日の經過に件ひ反射時の延長經過時 間及振幅高の減少を認む。非術側耳殼反 射は著變なし．第二群㵂猽に於ては術側 及非術側共に全観察期間を通じて著變を 認めず.

\section{第三章 總括並に考按}

レラミナリヤ7系を錐體骨塻下に充填せ る海猽に於ては何れも術後 3 日以內に於 て腦脊髓液壓の上昇を認むる方術後 7 日 に到れば再び下降して略健常時厴に復舊 す.

而して魚神經幹周圍に充㙋せる例及附 近に充戕せる例に於ては腦脊髓:夜壓の變 化怳態に著しき差違を認めず，唒顏面神 經末枌部感傅開放時電氣刺戟に低る耳款 攣縮運動は健常時術後を通じて異狀なき る憙神經幹周圍に充塡せる例のみに於て 術後衍側亘鄉性耳殼反射の振幅高經滥時 閒の減少反射時の延長を認む。郎ち㯖神 經幹周園充填例に於ける音響桦耳殼反射

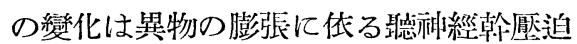
几起因し術後に於ける腦脊髓液壓の上昇 との間に直接的關係を認むるを得ず。河
野 ${ }^{11}$, 安野及龜谷 ${ }^{2)}$, 矢野原及柳原 ${ }^{31}$, 鹿沼 及片山 ${ }^{4}$ 請比の實驗の結哭に比較するに 余の實揽例に於ける腦冰髓液壓上昇は一 時的且輕微㲹して蝸牛敖栦經機能を障碍 するに到らざるに因るなるべし．

\section{結論}

1）泿猽頭蓋底骨膜下にレラミナリヤ 䒺を充填留㯰せる例に於ては術後一定時 間經過後一定度の腦春髓液壓上昇を認む。

2）術後一定度の腦脊髓液壓上昇を認

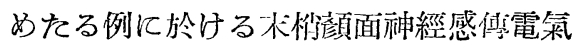
刺戟(R.A $10 \mathrm{~cm} .3 .0 \mathrm{~V}$ ) 亿低る耳殼等缩運 動の反射時，經過時間，振幅高に戀化を 認め才゙.

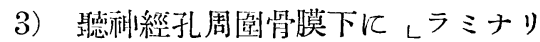
ヤフ系を充埧せる例に於ては術側音響性 耳没反射の反射時の延長經過時間及振幅 高の減少を認む。

4）䮡神經孔周圄より離隔せる部に レラミナリヤフ系を充崸せる例に於ては音 響性耳殼反射の反射時經過時間振幅高に 著變を認めず。 


\section{引用書 目}

（1）河野：聽覺生理補遺 腦壓變化の聽覺に及ぼす影響. 耳鼻咽喉科臨床第二十五尜四號.

（2）安部, 亀谷：腦壓上昇の音響性耳殼反射に及ぼす影響に就て耳鼻咽喉科臨床第二十忩一 號.

（3）腦壓變化の聽覺に及ぼす影響に就ての實驗的研究補遗 耳鼻咽喉科臨床第二十七爸二號.

（4）鹿沼，片山：頭蓋內血行障碍の音響性耳款反射に及ほ卞影響に就て。耳鼻咽喉科郜床第 二十二卷三號.

(5) 矢倉, 吉周 : 海猽第分腦神經幹前に第一中樞部露出方法に關する一考察. 